\title{
Gender Role Discrepancy, Discrepancy Stress, and Family Resilience of Minangkabau Family
}

\author{
Nurul Mukhlisah, Sri Redatin Retno Pudjiati \\ Faculty of Psychology, Universitas Indonesia, Indonesia \\ 10I17nm@gmail.com
}

\begin{abstract}
Family resilience is an important ability for family in facing various challenges throughout the lifespan. The study about family resilience of Minangkabau ethnic people needs further exploration due to the increase in divorce rate in the last three years, indicating that these families were not resilient. The cause of the divorce was related to matrilocal residency (husband lives in wife's house after marriage). This residency has the potential to cause the intervention of the wife's family to the relationship of husband and wife, therefore leading to the lack of authority in the husband's role. This condition poses a risk to husbands to experience gender role discrepancy and discrepancy stress. The purpose of this study was to examine the contribution of gender role discrepancy and discrepancy stress to family resilience by involving 139 Minangkabau men who lived in the wife's family house around the age 1850 years old. This study used a quantitative research method. Sampling technique used in this study was a purposive sampling technique. All data collected were analyzed by using multiple regression method. Results showed that gender role discrepancy and discrepancy stress contributed significantly to family resilience by $10.5 \%$. However, partial analysis showed that discrepancy stress alone did not contribute significantly to family resilience.
\end{abstract}

Keywords: discrepancy stress, family resilience, gender role discrepancy, minangkabau

\begin{abstract}
Abstrak
Resiliensi keluarga merupakan kemampuan yang penting dimiliki keluarga dalam menghadapi permasalahan di sepanjang rentang kehidupan. Penelitian mengenai resiliensi pada masyarakat Minangkabau perlu dilakukan karena terjadi peningkatan jumlah perceraian pada tiga tahun terakhir di Sumatera Barat yang menandakan bahwa keluarga tersebut tidak resilien. Penyebab perceraian pada masyarakat Minangkabau berkaitan dengan pola tempat tinggal matrilokal (suami tinggal ke rumah keluarga istri setelah menikah). Pola tempat tinggal ini berpotensi menyebabkan terjadinya keterlibatan keluarga istri terhadap hubungan pernikahan suami istri, sehingga peran suami di rumah keluarga istri tidak berjalan secara maksimal. Kondisi ini memberikan peluang bagi suami untuk mengalami gender role discrepancy dan discrepancy stress. Penelitian ini bertujuan untuk menguji kontribusi gender role discrepancy dan discrepancy stress terhadap resiliensi keluarga pada keluarga Minangkabau dengan melibatkan 139 laki-laki Minangkabau yang tinggal di rumah mertua yang berusia 18-50 tahun. Penelitian ini menggunakan metode penelitian kuantitatif. Teknik pengambilan sampel yang digunakan pada penelitian ini adalah teknik purposive sampling. Data partisipan diolah menggunakan metode analisis berganda. Hasil penelitian ini menunjukkan bahwa gender role discrepancy dan discrepancy stress secara bersama-sama berkontribusi secara signifikan terhadap resiliensi keluarga sebesar $10.5 \%$. Namun analisis parsial menunjukkan bahwa discrepancy stress tidak berkontribusi secara signifikan terhadap resiliensi keluarga
\end{abstract}

Keywords: perbedaan stres, ketahanan keluarga, perbedaan peran gender, minangkabau 


\section{Introduction}

Every family face problems and challenges throughout the life span that can disrupt the family as a whole. In facing problems and challenges, the family plays a role to protect the family members due to the changes in family structure. How a family responds and manages problems and challenges determines the family's ability to adapt positively in crisis life events (Herdiana, Suryanto, \& Handoyo, 2018). The ability to adapt positively and successfully in crisis life events is described as family resilience which is salient to help the family to conquer the adversities and promote the development of family members. Family resilience is defined as the ability or capacity to withstand, adapt positively, and even bounce back in facing various challenges in life (Walsh, 2016a). According to Walsh (2016a), the concept of family resilience was developed based on family system theory, suggests that crises, challenges, and adversities have an impact on family members and the family as a unit, and family process in facing the crisis mediate the ability of family members to adapt successfully and become more resourceful.

Recently, the focus of family resilience research has been extended to understand the family resilience of ethnic families. Family resilience scientists recognized the limitation of family resilience research related to the diversity of values, beliefs, and identities of ethnic families in dealing with various events in their lives and supporting the resilience of the families (McCubbin \& McCubbin, 2013). Most of the early studies of family resilience used methods and theories that related to Western culture and white people; therefore, the results of the studies cannot be applied in studying ethnic families. It is necessary to consider the context and culture to understand the family resilience of ethnic families to identify the coping strategies that do not appear when only defining resilience from the perspective of Western culture and white people (Ungar, 2012).

Indonesia has many ethnicities that have different values and family dynamics, resulting in the different processes to establish family resilience. A previous study on the family resilience of Batak Toba families showed that family strain and coping contributed directly to family resilience, meanwhile community support mediated the contribution of cultural identity and socioeconomic status (Pudjiati, 2016). A study about family resilience of Javanese families examined the mediating role of cognitive appraisal of the relationship between cultural identity and family resilience (Azizah \& Pudjiati, 2020). Results of the study showed that the mediating role of cognitive appraisal was not significant, indicating that cultural identity contributed directly to family resilience in Javanese families. Another study about Javanese families found the similar result that cultural identity contributed directly and positively to family resilience (Kristiyani \& Pudjiati, 2019).

These factors of family resilience in the Batak Toba family might be different from other ethnic families in Indonesia, for Minangkabau ethnic families due to their adherence to different kinship system with Batak Toba ethnic group and most other ethnic groups in Indonesia. Minangkabau people, the native group of West Sumatera, adhere to a matrilineal kinship system that inherits the lineage from the mother.

Recently, there was a phenomenon in Minangkabau people in West Sumatera, that was the increasing rate of divorce for the last three years by 59.1\% from 2017 to 2019 (Badan Pusat Statistik Povinsi Sumatera Barat, 2020). The increase in the divorce rate indicates the declining ability of families to manage and maintain family functioning (Azizah \& Pudjiati, 2020), therefore the process and factors of Minangkabau people's family resilience need further exploration. There were some causes of divorces in West Sumatera, those three dominant causes were no commitment between spouses, no compatibility to each other, and third-party interference. The last cause, in West Sumatera, seemed to be increasing over the years, this was coming from the spouse's relatives (Bulan \& Lastriyah, 2016). This condition is very likely to happen in West Sumatera due to the matrilocal residency, i.e., husband goes to live with the wife's family after marriage.

In traditional matrilocal residency, the wife's brother, called mamak, looked after children and women. Meanwhile, the husband in the wife's family did not have a significant role, because he was considered as a 'guest' in the wife's family. He had no authority in taking care of his children and wife, both financially and morally (Syahrizal \& Meiyenti, 2012). However, though Minangkabau society 
changed due to civilization development, they still maintain the matrilocal residency leading to the continuity of the lack of authority in the husband's role.

A recent study found that kinship systems, matrilineal and patrilineal kinship systems, played a role in husband's marital satisfaction who lived with their wife's family (Putri \& Hermaleni, 2019). Husbands from the Minangkabau ethnic group who adhere to matrilineal kinship system had low scores in marital satisfaction, whereas husbands from Javanese ethnic group who adhere to patrilineal kinship system had very high scores in marital satisfaction. Putri \& Hermaleni (2019) suggested that this result happened due to the differences in cultural views about the position and role of husband in extended family. In Javanese ethnic group, the husband is considered as the main household leader who has great authority in the family (Putri \& Lestari, 2015). Meanwhile, in the Minangkabau ethnic group, the husband is considered as a 'guest' who has a low authority in the wife's family (Meiyenti \& Afrida, 2018). Therefore, this view affects how a husband is treated in his wife's house and how he behaves among his wife's family.

Minangkabau men in general have two roles, as a mamak and urang sumando. As a mamak, Minangkabau men play a role as a leader for their matrilineal family. As a urang sumando, they play a role as a guest who has a low authority in the wife's family. Both roles demand independence from Minangkabau men, so the gender socialization for Minangkabau boys focused on preparing them to become independent men. In rumah gadang or Minangkabau traditional house, the boys had no room because the rooms in the house were only made for the girls and their husbands (Naim, 2013). At a young age, the boys slept in the living room and as they grew older, they slept in surau. In surau, the boys learned various knowledge and skills, such as reciting al-Qur'an, learning silat, and other skills to prepare themselves to become independent.

In Minangkabau modern society, these two roles of men had changed, which were the weakening the role of mamak and the strengthening role of husband as father (Meiyenti \& Afrida, 2018). Minangkabau men spend more time with their wife and children and rarely visit their matrilineal families, mainly for those who live separately from their parents (Bakti, 2014). However, for families who still maintain the matrilocal residency, the men's role as husband are still weak, as described above. Moreover, the gender socialization for Minangkabau boys were no longer found in Minangkabau modern society, as well as the increasing education level, media and other culture exposures resulting in the differences in the view about gender role between Minangkabau modern and traditional men. The view of gender role has changed but the Minangkabau modern men are still having to maintain the matrilocal residency, therefore their role in the wife's family house have the potential to cause a discrepancy between his view of man gender role and the gender role he lives in. This discrepancy is called gender role discrepancy.

According to Pleck (1995), men experience gender role discrepancy when they fail in achieving the best version of men's role that results in viewing themselves and/or having a thought of people judging them as less masculine. This discrepancy leads to discrepancy stress, i.e., stress that emerges from experiencing gender role discrepancy (Reidy Berke, Gentile, \& Zeichner., 2014). Experience of gender role discrepancy and discrepancy stress is the consequence of cultural standards of masculinity on gender socialization (Pleck, 2017). These cultural standards expect men to hide vulnerable emotions and become tough and rough, therefore the inability to meet these standards results in negative selfappraisal and judgment from others (Pleck, 1995). Previous studies showed that gender role discrepancy and discrepancy stress were associated with partner violence and mental health problems (Reidy, Berke, Gentile, \& Zeichner, 2014; Reidy, Brookmeyer, Gentile, Berke, \& Zeichner, 2016; Reidy, Smith-Darden, Vivolo-Kantor, Malone, Kernsmith, 2018). Men who perceive themselves to be less masculine will consider an ambiguous interaction as a threat to their masculinity. This condition leads the men to respond by demonstrating their masculine side even more and sometimes through aggressive behaviors (Reidy Berke, Gentile, \& Zeichner., 2014; Berke, Reidy, Miller, \& Zeichner, 2017).

Though discrepancy stress occurs due to the experience of gender role discrepancy, but previous study had proven that the men who experience gender role discrepancy do not always experience discrepancy stress (Reidy Berke, Gentile, \& Zeichner, 2014; Reidy, Brookmeyer, Gentile, Berke, \& 
Zeichner, 2016). Men who experience gender role discrepancy might develop negative self-evaluation and develop the idea that people judge them negatively, but men who experience high levels of discrepancy stress have a greater tendency to engage in risky behaviors. Therefore, discrepancy stress is associated with more severe maladaptive behaviors and mental health problems than gender role discrepancy (Reidy Berke, Gentile, \& Zeichner, 2014; Reidy, Brookmeyer, Gentile, Berke, \& Zeichner 2016; Yang, Lau, Wang, Ma, \& Lau., 2018).

Gender socialization has a role in family resilience, specifically in the communication process of a family. Walsh (2003) suggested that gender socialization causes individual differences in responding to crisis and adverse situations, women are more open in expressing sadness and anxiety, while men tend to get angry and withdraw. Masculine stereotypes often prevent men from showing vulnerable emotions such as sadness, fear, and anxiety because men are expected to be tough and strong. When these vulnerable emotions cannot be expressed openly and shared with the family members, it can lead to negative consequences such as depressive symptoms, self-harm behaviors, and conflicts among the family members (Walsh, 2003).

Gender role discrepancy and discrepancy stress impact negatively on the individual and family member, as described above. Based on family system theory, the problems and challenges faced by a family member will also have an impact on the family as a functional unit (Walsh, 2012). The problems and challenges are considered as risk factors that can interfere with the family and disrupt the family resilience. The study about the impact of problems and challenges for family resilience in matrilocal residency related to the husband's role in the family is still limited. The previous study about family resilience in matrilocal residency was conducted on the wives and reported that wives' external and internal stress contributed as risk factors for family resilience in matrilocal residency (Elvika \& Pudjiati, 2019). Matrilocal residency poses risks not only for the wife but also for the husband due to the lack of authority in the husband role that can lead to the experience of gender role discrepancy and discrepancy stress. Therefore, this study aimed to test the contribution of gender role discrepancy and discrepancy stress on the family resilience of the Minangkabau ethnic families.

\section{Method}

This study used the non-experimental and quantitative research method to test all the variables. The variables tested in this study were gender role discrepancy, discrepancy stress, and family resilience.

The characteristics for subjects were Minangkabau married men around the ages of 18-50 who lived in the wife's family house. The age criteria were set because it can affect gender role discrepancy and discrepancy stress. During the transition to adulthood, men are more likely to experience gender role discrepancy and discrepancy stress due to the instability of the identity and the increasing desire to engage in risky behaviors. The tendency to experience gender role discrepancy and discrepancy stress also increases when men experience role changes, such as becoming a husband and a father. However, at the age of 55 years, study showed that men tend to view masculinity more flexibly. The wives of subjects are also from Minangkabau because the matrilocal tradition is only applied to married couples who both come from Minangkabau. If one of the husband or wives is not from Minangkabau, typically the family does not strictly apply the matrilocal tradition.

Subjects were recruited in Kabupaten 50 Kota using the purposive sampling method. subjects were asked to complete a self-report questionnaire that consists of demographic data and research instruments. Before being asked to complete the questionnaire, subjects were asked for their consent to participate in this study, and they were allowed to stop participating at any time. Initially there were 148 subjects that participated in this study, but we excluded 9 subjects due to the incomplete data.

The measures used in this study were Masculine Discrepancy Stress Scale (MDSS; Reidy, Berke, Gentile, \& Zeichner, 2014) and Walsh Family Resilience Questionnaire (WFRQ; Walsh, 2016b). Masculine Discrepancy Stress Scale (MDSS) was used to measure gender role discrepancy and discrepancy stress. This measure consists of 10 items, 5 items assess the level of gender role 
discrepancy, and 5 items assess the level of discrepancy stress. Response options range from strongly agree (1) to strongly disagree (4). Cronbach's alpha for gender role discrepancy subscale was .91 and for discrepancy stress subscale was .86 .

We adapted MDSS to Bahasa using the guidelines proposed by Beaton, Guillemin, \& Ferraz (2000) in adapting self-report measures in a cross-cultural context. This adaptation process consisted of five stages. In Stage 1, the scale was translated to Bahasa by two translators whose first language was Bahasa. We set criteria for translators in this step, which was fluency in English as indicated by IELTS score. The first translator had an IELTS score of 7 who was a student in The University of Exeter and the second translator had an IELTS score of 6.5 who is currently a student in The University of Wyoming. One of these translators was not aware of the concepts being quantified in the scale, to describe the language used in every life.

Stage 2 involved the synthesis process of the two translations. We identified and resolved the discrepancies between two translations to produce one translation. The translation produced in stage 2 was translated back to English in stage 3 by two translators with English as their first language. This process was conducted to check the validity of the items, whether the Bahasa version was reflecting the same concept as the original English version. This process produced two translations. Stage 4 was the expert committee process to combine and integrate the entire translation versions. This process was the most important to attain equivalence between English and Bahasa versions. Last, stage 5 was the test of the pre-final version which was conducted to 43 Minangkabau men. Results of the try-out process showed that Cronbach's alpha for gender role discrepancy subscale was .92 and for discrepancy stress subscale was .752.

Family resilience was measured by using Walsh Family Resilience Questionnaire (WFRQ). WFRQ was adapted into Bahasa by Pudjiati (2016) and consists of 36 items to measure three key processes of family resilience i.e., family's system belief, communication process, and organizational process. Response options range from strongly agree (1) to strongly disagree (4). Cronbach's alpha for WFRQ was .94. We also tested the scale on 43 Minangkabau men and the try-out process showed Cronbach's alpha for WFRQ was .951.

All data collected were analyzed using multiple regression analyses methods to test the contribution of gender role discrepancy and discrepancy stress as independent variables to family resilience as dependent variables. The analyses were performed by using SPSS 22 .

\section{Results}

Most subjects in this study were around the ages 20-39, work as a freelancer and have secondary education level. Most subjects married for less than 5 years and lived in the wife's family house for less than 5 years. Most subjects lived with both mother and father-in-law. Last, not having a personal house was the dominant reason for living in the wife's family house.

The descriptive analysis showed that, based on hypothetical mean, the level of family resilience in most subjects was high $(76.97 \%)$, the level of gender role discrepancy and discrepancy stress in most subjects was low $(94.96 \%$ \& $79.85 \%)$. These results are shown in Table 1.

Table 1: The Categorization of Most Subjects Based on Hypothetical Mean

\begin{tabular}{lccc}
\hline \multicolumn{1}{c}{ Variable } & Category & Percentage & Mean \\
\hline Family Resilience & High & $76.97 \%$ & 108 \\
Gender Role Discrepancy & Low & $94.96 \%$ & 12.5 \\
Discrepancy Stress & Low & $79.85 \%$ & 12.5 \\
\hline
\end{tabular}


Results in Table 2 show that education level and gender role discrepancy were correlated significantly with family resilience. No significant correlations were found between family resilience, age, marriage period, duration of living in the wife's family house, and discrepancy stress.

Table 2: Correlations of all variables

\begin{tabular}{clccccccc}
\hline No. & \multicolumn{1}{c}{ Variables } & 1 & 2 & 3 & 4 & 5 & 6 & 7 \\
\hline 1 & Age & 1 & & & & & & \\
2 & Education level & $-.253^{* *}$ & 1 & & & & & \\
3 & Marriage period & $.589^{* *}$ & $.589^{* *}$ & 1 & & & & \\
4 & Duration of living in the & $.548^{* *}$ & $-.263^{* *}$ & $.927^{* *}$ & 1 & & & \\
& wife's family house & & & & & & & \\
5 & Gender role discrepancy & -.026 & $.233^{* *}$ & -.021 & -.065 & 1 & & \\
6 & Discrepancy stress & .029 & .029 & -.108 & $-.170^{*}$ & & 1 & \\
7 & Family resilience & -.0 .016 & $.214^{*}$ & .127 & .072 & $.294^{* *}$ & .116 & 1 \\
\hline
\end{tabular}

Multiple regression analysis was performed to test the contribution of gender role discrepancy and discrepancy stress on the family resilience of Minangkabau ethnic families. The results showed gender role discrepancy and discrepancy stress were contributed significantly to family resilience $\left(\mathrm{R}^{2}=\right.$ $.105, \mathrm{p}<.05)$. However, the partial analysis showed that discrepancy stress did not contribute significantly to family resilience $(p>.05)$. These results are shown in Table 3.

Table 3: Multiple regression analysis of family resilience on gender role discrepancy and discrepancy stress.

\begin{tabular}{lccccccc}
\hline \multicolumn{1}{c}{ Variables } & R & $\begin{array}{c}\text { Adjusted } \\
\text { R Square }\end{array}$ & F & Sig. F & Beta & T & $\begin{array}{c}\text { Sig. } \\
\text { Beta }\end{array}$ \\
\hline $\begin{array}{l}\text { Gender Role } \\
\text { Discrepancy }\end{array}$ & .105 & .092 & 8.006 & .001 & & & \\
$\begin{array}{l}\text { Discrepancy } \\
\text { Stress }\end{array}$ & & & & & 2.153 & 3.738 & 0.00 \\
\hline
\end{tabular}

The result of this study indicated that gender role discrepancy and discrepancy stress played a role as risk factors together for family resilience in matrilocal residence of Minangkabau ethnic families. However partial analysis showed that gender role discrepancy contributed significantly to family resilience, but discrepancy stress did not contribute significantly.

\section{Discussion}

The significant contribution of gender role discrepancy is consistent with several previous studies that found gender role discrepancy had negative impacts on the individual and the family (Reidy, Berke, Gentile, \& Zeichner, 2014; Reidy, Brookmeyer, Gentile, Berke, \& Zeichner, 2016; Reidy, Smith-Darden, Vivolo-Kantor, Malone, \& Kernsmith, 2018). The correlation between gender role discrepancy and family resilience was positive, meaning that the increasing score of gender role discrepancy (low gender role discrepancy) was followed by the increasing score of family resilience. This result suggests that the husband's role and position in matrilocal residence might lead to the experience of gender role discrepancy resulting in the decrease of the family resilience 's level.

Previous research showed that men are expected to be strong, confident, and show no weakness (Berke \& Zeichner, 2016; Vandelo \& Boston, 2013), which becomes the standard for the ideal male 
figure. The inability to achieve this ideal figure leads to the negative evaluations of the individual and others. Masculine gender stereotypes can limit a man's ability to express vulnerable emotions openly with other family members (Walsh, 2003). If vulnerable emotions cannot be shared with other family members, the family cannot give each other empathy in dealing with problems and crisis situations. This condition can impact the communication process within the family, because to establish family resilience, the family members should communicate openly and clearly to each other (Walsh, 2016a).

While gender role discrepancy predicted family resilience, on the other hand, discrepancy stress did not predict the family resilience of Minangkabau families. This result was inconsistent with previous studies that reported the negative consequences of discrepancy stress on individual and family such as partner violence, emotion regulation difficulties, and mental health problems (Berke, Reidy, Gentile, \& Zeichner, 2016; Reidy, Berke, Gentile, \& Zeichner, 2014; Reidy, Smith-Darden, VivoloKantor, Malone, \& Kernsmith, 2018; Yang, Lau, Wang, Ma, \& Lau. 2018). Results of this study suggest that Minangkabau husbands who live in the wife's family house might experience gender role discrepancy, but not discrepancy stress. These results can be explained by research conducted by Haque, Aston, \& Kozlovski (2016) that found the causes of stress in men typically were things related to work, while problems that occur in the family were usually the cause of stress in women. In addition, we suspect that the contribution of discrepancy stress to family resilience does not occur directly. Reidy, Reidy, Smith-Darden, Vivolo-Kantor, Malone, \& Kernsmith, (2018) suggested that men who have the potential to experience discrepancy stress which can lead to the negative consequences are men who consider masculine gender roles to be salient. As stated by Reidy, Brookmeyer, Gentile, Berke, \& Zeichner (2016), the men who experienced gender role discrepancy and perceived that condition as distress, wanted to show their masculinity by doing risk behaviors and have more mental health problems. On the other hand, the men who experienced gender role discrepancy were not distressed by their condition and were less likely to experience negative consequences.

We assumed that Minangkabau husband in matrilocal residency did not experience discrepancy stress due to the Minangkabau culture itself. Minangkabau people's way of life is reflected in adat which contains values, norms, and laws that have been transmitted over generations and still maintained until now (Ilmi, 2015). Minangkabau's adat also had the rule about social norms that can be applied in matrilocal residence to minimize conflict between family members. This rule was called kato nan ampek, which consisted of four language styles when interacting with people based on their age (Sulaeman, Fauziah, Rahman, Anggraini, Chandra, \& Sakti, 2019). Kato mandaki is a language style to use when interacting with older people, kato malereng is for interacting with a respected person, kato mandata is for interacting with peers, and last, kato manurun is used when interacting with younger people. The family members who understand and internalize these cultural social norms can maintain a good relationship in the family and establish family resilience.

\section{Conclusion}

Based on the results of this study, we can conclude that gender role discrepancy and discrepancy stress contributed significantly to the family resilience of Minangkabau families, but no significant contribution was found for discrepancy stress. To our knowledge, this is the first study that tested the risk factors experienced by husbands and their relation to family resilience. This study also considered a cultural context in exploring the family resilience of ethnic families. This study gives the contribution to family resilience research in Indonesia families, in particular Minangkabau families. The results of this study can be used as a reference in developing a program to support family resilience in Minangkabau ethnic families.

We recognized limitations of this study. For the sample criteria we only control the age of the subjects without controlling other factors that can affect the results. The contribution of gender role discrepancy and discrepancy stress to family resilience in this study was relatively low (10.5\%), indicating that $89.5 \%$ was predicted by other factors. 
The next study may examine other factors that are expected to give a bigger contribution to the family resilience of Minangkabau families. This study only tested the risk factors of family resilience therefore the dynamic process of risk and protective factors on family resilience were still not seen. Examining both risk and protective factors is necessary for the next study.

\section{References}

Azizah, L.N., \& Pudjiati, S.R.R. (2020). Kontribusi identitas budaya jawa yang dimediasi oleh cognitive reappraisal dalam membentuk resiliensi keluarga pada keluarga suku Jawa. Analitika: Jurnal Magister Psikologi $U M A, \quad 12 \quad$ (1): 10 21.https://doi.org/10.31289/analitika.v12i1.2815

Bakti. (2014). Pergeseran peranan laki-laki dalam masyarakat Minangkabau. Antropologi, 47, 111114.

Beaton, D. E., Bombardier, C., Guillemin, F., \& Ferraz, M. B. (2000). Guidelines for the process of cross-cultural adaptation of self-report measures. Spine, 25(24), 3186-3191.

Badan Pusat Statistik Provinsi Sumatera Barat. (2020). Provinsi Sumatera Barat dalam Angka. CV Petratama Persada.

Berke, D. S., \& Zeichner, A. (2016). Man's heaviest burden: A review of contemporary paradigms and new directions for understanding and preventing masculine aggression. Social and Personality Psychology Compass, 10(2), 83-91. https://doi.org/10.1111/spc3.12238

Berke, D. S., Reidy, D. E., Miller, J. D., \& Zeichner, A. (2017). Take it like a man: Genderthreatened men's experience of gender role discrepancy, emotion activation, and pain $\begin{array}{llllll}\text { tolerance. Psychology of Men \& Masculinity, } & \text { 18(1), } & 62 .\end{array}$ http://dx.doi.org/10.1037/men0000036

Bulan, E.R., \& Lastriyah, (2016). Fenomena peningkatan cerai gugat di Padang: Indikasi kebangkitan perempuan? Dalam Kustini \& I. Rosidah (Eds.), Ketika perempuan bersikap: tren cerai gugat masyarakat muslim (hal. 75-135). Puslitbang Kehidupan Keagamaan.

Elvika, R. R., \& Pudjiati, S. R. R. (2019). Kontribusi stres eksternal dari gangguan sehari-hari dan stres internal terhadap resiliensi keluarga masyarakat matrilineal Minangkabau. Analitika: Jurnal Magister Psikologi UMA, 11(1), 46-59. https://doi.org/10.31289/analitika.v11i1.2405

Haque, A. U., Aston, J., \& Kozlovski, E. (2016). Do causes and consequences of stress affect genders differently at operational level? Comparison of the IT sectors in the UK and Pakistan. International Journal of Applied Business and Management Studies, 1(1), 1-7.

Herdiana, I., Suryanto, \& Handoyo, S. (2018). Family resilience: A conceptual review. Advance in Social Science. Education and Humanities Research, 133, 42-48. https://doi.org/10.2991/acpch-17.2018.9

Ilmi, D. (2015). Pendidikan karakter berbasis nilai-nilai kearifan lokal melalui ungkapan bijak Minangkabau. ISLAM REALITAS: Journal of Islamic \& Social Studies, 1(1), 45-54. http://dx.doi.org/10.30983/islam_realitas.v1i1.7

Kristiyani, V., \& Pudjiati, S. R. R. (2019). Parenting stress sebagai prediktor dalam pembentukan resiliensi keluarga yang dimoderasi oleh identitas budaya Jawa. Analitika: Jurnal Magister Psikologi UMA, 11(1), 60-71. https://doi.org/10.31289/analitika.v11i1.2408

McCubbin. L.D. \& McCubbin, H. I. (2013). Resilience in ethnic family systems: A relational theory for research and practice. Dalam D Becvar (Ed.), Handbook of Family Resilience (pp. 175-195). Springer. 
Meiyenti, Sri \& Afrida. (2018). The inequality of right and obligation of minangkabau men in matrilineal system. Jurnal Ilmu Sosial Mamangan, 7 (1), 12-22. https://doi.org/10.22202/mamangan.2466

Naim, M. (2013). Merantau pola migrasi suku Minangkabau. Edisi ketiga. Rajawali Press.

Pleck, J. H. (1995). The gender role strain paradigm: An update. Dalam R. F. Levant \& W. S. Pollack (Ed.), A new psychology of men (pp. 11-32). Basic Books/Hachette Book Group.

Pleck, J. H. (2017). Foreword: A brief history of the psychology of men and masculinities. The psychology of men and masculinities (pp. xi-xxi). American Psychological Association.

Pudjiati, S. R. R. (2016). Model resiliensi keluarga: Pengaruh identitas budaya, coping, family strain, status sosial ekonomi dan dukungan komunitas dalam pembentukan resiliensi keluarga pada suku bangsa Batak Toba. [Unpublished dissertation]. Universitas Indonesia.

Putri, D. P. K., \& Lestari, S. (2016). Pembagian peran dalam rumah tangga pada pasangan suami istri Jawa. Jurnal Penelitian Humaniora, 16(1), 72-85. https://doi.org/10.23917/humaniora.v16i1.1523

Putri, R.E., \& Hermaleni, T. (2019). Perbedaan kepuasan pernikahan laki-laki yang tinggal di rumah mertua ditinjau garis keturunan. Jurnal Riset Psikologi, 2019(3). http://dx.doi.org/10.24036/jrp.v2019i3.7095

Reidy, D. E., Berke, D. S., Gentile, B., \& Zeichner, A. (2014). Man enough? Masculine discrepancy stress and intimate partner violence. Personality and Individual Differences, 68, 160-164. https://doi.org/10.1016/j.paid.2014.04.021

Reidy, D. E., Brookmeyer, K. A., Gentile, B., Berke, D. S., \& Zeichner, A. (2016). Gender role discrepancy stress, high-risk sexual behavior, and sexually transmitted disease. Archives of Sexual Behavior, 45, 459-465. https://doi.org/10.1007/s10508-014-0413-0

Reidy, D. E., Smith-Darden, J. P., Vivolo-Kantor, A. M., Malone, C. A., \& Kernsmith, P. D. (2018). Masculine discrepancy stress and psychosocial maladjustment: Implications for behavioral and mental health of adolescent boys. Psychology of Men \& Masculinity, 19(4), 560-569. https://doi.org/10.1037/men0000132

Sulaeman, Y., Fauziah, M., Rahman, A. E., \& Chandra, A. W. (August 29-30, 2019). Implementation kato mandaki of civility Minangkabau community in Rangkasbitung [paper presentation]. The 2nd International Conference on Local Wisdom (INCOLWIS), Padang, West Sumatera, Indonesia. https://doi.org/10.4108/eai.29-8-2019.2289102.

Syahrizal \& Meiyenti, Sri. (2012). Sistem kekerabatan Minangkabau kontemporer: Suatu kajian perubahan dan keberlangsungan sistem kekerabatan matrilineal Minangkabau [paper presentation]. The 4th International Conference on Indonesian Studies: Unity, Diversity and Futur, Universitas Andalas, Padang, West Sumatera, Indonesia.

Ungar, M. (2012). Researching and theorizing resilience across cultures and contexts. Preventive Medicine: An International Journal Devoted to Practice and Theory, 55(5), 387389. https://doi.org/10.1016/j.ypmed.2012.07.021

Vandello, J. A., \& Bosson, J. K. (2013). Hard won and easily lost: A review and synthesis of theory and research on precarious manhood. Psychology of Men \& Masculinity, 14, 101-113. https://doi.org/10.1037/a0029826

Walsh, F. (2003). Family resilience: A framework for clinical practice. Family Process, 42(1), 118. https://doi.org/10.1111/j.1545-5300.2003.00001.x 
Walsh, F. (2012). Clinical views of family normality, health, and dysfunction: from a deficit to a strength's perspective. Dalam Froma Walsh (Ed.), Normal family processes: Growing diversity and complexity (pp. 27-54). Guilford Press.

Walsh, F. (2016a). Family resilience: a developmental systems framework. European journal of developmental psychology, 13(3), 313-324. https://doi.org/10.1080/17405629.2016.1154035

Walsh, F. (2016b). Strengthening family resilience. (3rd ed). The Guilford Press.

Yang, X., Lau, J. T., Wang, Z., Ma, Y. L., \& Lau, M. C. (2018). The mediation roles of discrepancy stress and self-esteem between masculine role discrepancy and mental health problems. Journal of Affective Disorders, 235, 513-520. https://doi.org/10.1016/j.jad.2018.04.085 